\title{
Character Values Represented in Tembang Sunda Cianjuran
}

\author{
Aprilla Adawiyah $^{\mathrm{a}, 1}$ dan Mia Fatimatul Munsi ${ }^{\mathrm{a}, 2}$

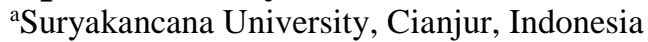 \\ ${ }^{1}$ aprilla.adawiyah@gmail.com; ${ }^{2}$ miafatimatulmunsi88@gmail.com
}

\begin{tabular}{ll}
\hline Article info & A B S T R A C T \\
\hline Article history: & This study is aimed at describing character values in five \\
Revised : 24-08-2019 & Cianjuran Sundanese songs (Tembang Sunda Cianjuran) \\
Accepted: 20-09-2019 & comprising Laut Kidul, Mairan ti Dapur Yayasan Wargi Cianjur, \\
& Itu Gunung Naon Raden, Pamoyanan, and Kidung Wiwitan, taken \\
& from a book entitled Ngauguar Mamaos Cianjuran. These songs \\
& were chosen due to their lyrics which are easily understandable, \\
& full of character values and highly related to the locality of \\
& Cianjur. This article is based upon the analytic Descriptive \\
& method with a literature review used to examine and describe \\
& character values in Tembang Sunda Cianjuran. From eighteen \\
& character values, only thirteen character values are found in the \\
& songs. They are religiosity, honesty, discipline, hard work, \\
& creativity, curiosity, national spirit, patriotism, appreciation of \\
& achievement, communication, reading habits, environmental care, \\
& and responsibility values. In the current songs, the most \\
& frequently occurring value is patriotism, which is contained in the \\
& second song (TSC-O2). It has nine character values. Cianjuran \\
& Sundanese songs function as the guiding norm of life, related to \\
& religion, and contains advice so that humans could behave in \\
& compliance with religion, the human and Creator relationship, as \\
& well as the human and environment relationship.
\end{tabular}

Keywords:

character values Cianjuran

Mamaos

songs

Sundanese
Studi ini bertujuan mendeskripsikan nilai-nilai karakter dalam lima tembang Sunda Cianjuran yang terdiri atas Laut Kidul, Mairan ti Dapur Yayasan Wargi Cianjur, Itu Gunung Naon Raden, Pamoyanan, dan Kidung Wiwitan, yang diambil dari buku Ngaguar Mamaos Cianjuran. Tembang-tembang tersebut dipilih karena liriknya lebih mudah dipahami, mengandung nilai karakter, dan berkaitan erat kaitannya dengan lokalitas Cianjur. Metode yang digunakan adalah metode deskriptif analitik dengan teknik telaah pustaka untuk menelaah dan mendeskripsikan nilainilai karakter dalam tembang Sunda Cianjuran. Dari 18 nilai karakter, hanya 13 nilai karakter yang terdapat dalam tembang tersebut, berupa nilai religius, nilai jujur, nilai disiplin, nilai kerja keras, nilai kreatif, nilai rasa ingin tahu, nilai semangat kebangsaan, nilai cinta tanah air, nilai menghargai prestasi, nilai komunikatif, nilai gemar membaca, nilai peduli lingkungan, dan nilai tanggung jawab. Nilai karakter yang paling sering muncul adalah nilai cinta tanah air. Tembang Sunda Cianjuran memiliki fungsi bagi masyarakat sebagai salah satu acuan dalam kehidupan di dunia, berkaitan dengan agama, dan berisi nasihat agar manusia berperilaku sesuai dengan ajaran agama, berkaitan dengan hubungan manusia dengan sang Maha Pencipta, hubungan manusia dengan manusia, dan hubungan manusia dengan 


\section{INTRODUCTION}

Character is fundamental and highly essential for humans because it is the characteristic and identity of humans. This is in a similar vein with Supriyono, Wardani, \& Saddhono (2018) that character values constitute the most important aspect in life in the 21 st century, required to be developed through learning processes. Character values reflected in national culture can be used as models and be appreciated by the community. Similarly, cultural diversity must always be appreciated and upheld by Indonesian people because culture shows national identity and the characteristics of the nation. However, the young generation is now starting to forget the character and culture of the country as reflected in the degradation of acceptable behavior among them. Such acceptable behavior and character are dependent on the culture and local wisdom as they function as guidance to enlighten the right way and orientation to people's life (Koentjaraningrat, in Adawiyah \& Munsi, 2018). In this regard, the character is the identity, the personality and the disposition of a person (Gufron, 2010). Hence, an analysis of character that belongs to a community is required to reveal the virtues and identity ideally possessed by the community for societal and educational purposes.

Cianjur, as Maryam (2012) explains, has extremely good philosophy, namely ngaos (religiosity), mamaos (culture), and maenpo (hard work/toughness/skills), but the philosophy is not optimally practiced. The practice of the given philosophy might be exposed to Globalization that brings people into the global network system whose goal is to change the civilization. This circumstance demands people's adaptation to the globalization era. Concerning this, a problem may arise as the culture cannot adapt to globalization and stops progressing as a result of a lack of interest in culture. This may result in cultural alteration and the local wisdom may be replaced (Ihgbal, 2017). In a similar vein, Hurri \& Munajat (n.d.) argue that globalization brings not only positive effects but also numerous negative effects signified by the eroded values of local wisdom entailing ngaos, mamaos, and maenpo among the Sundanese community. 
The Cianjur community has an identity known as seven cultural pillars, encompassing ngaos (reading Al-Quran), mamaos (tembang, humming or sing Cianjuran), maenpo (pencak silat, martial arts), tatanen (everything related to agriculture), Tangginas (agile, skillful), sauyunan (working together), and someah or friendly (Maulana, 2018). These seven pillars must continue to be preserved by the community; one of its efforts is to introduce Cianjur cultures to the community and the younger generation. Hence, this research is intended to study the character values in the lyrics of Tembang Sunda Cianjuran (Cianjuran Sundanese songs).

Tembang is one part of karawitan. Ischak (2006) states that the sound art repertoire of Sundanese music is divided into two parts, namely "kawih" and "tembang". Kawih is defined as the art of sound with a regular or rhythmic rhythm, while the song means the type of sound art which is free (merdika), but is still bound by rules that are determined by the forms of pupuh or guguritan. In addition, Wiradiredja (2012) defines Cianjuran Sundanese songs as Sundanese musical art accompanied by musical intruments such as kacapi indung, kacapi rincik, suling, dan rebab. Cianjuran Sundanese Songs mean Sundanese songs with Cianjur style possessing two elements, comprising the vocal element (songs) sung by man and women singers and the instrumental element (the sound of musical instruments) from a set of musical instruments. Of the two elements, the vocal element (songs) constitues the main element of Cianjuran Sundanese songs (Hermawan, 2014).

Society and art, usually have a close relationship. Art is considered something that is so close to society. Likewise, Tembang Sunda Cianjuran is considered as a part of art belonging to the Sundanese people, because it originates and is rooted in the surrounding community environment (Ischak, 2006). Similarly, the Cianjur community still considers that Tembang Sunda Cianjuran was born, grown and developed in the environment in Padaleman Cianjur and then spread accordingly. Furthermore, it is stated that values which are able to provide guidance and moral education as well as subtle character lie in Cianjuran Sundanese songs. Besides, Hotimah (2018) adds that rumpaka of Cianjuran Sundanese Songs has good quality in terms of the theme, the grammar, and the meaning. 
Tembang Sunda Cianjuran has three meanings (Natamihardja, 2009). Firstly, based on the origin of the word (etymology), mamaos comes from the word maos, another term of maca (reading). The word maca becomes maos which means a lot of reading, not only reading a piece of writing. Secondly, mamaos or mamaca means reading the entire creation of the Creator; maca the relationship between humans and other humans, maca the relationship between humans and the surrounding nature, maca the relationship between living things with other living things created by the Creator. The word mamaos is known and is only found in Cianjur, while in other areas it is called Tembang Sunda Cianjuran. Based on Sundanese music, karawitan was born in the 1930's while mamaos existed since the 18th century and began to be accompanied by musical instruments. Thirdly, in a broad sense, "kecap mamaos ngandung harti seueur anu dibaca, rupa-rupaning kaayaan turta kajadian aya dina kecap mamaos. Mana komo, apan dina mamaos teh dibagi ku sababaraha wanda"; the meaning is that "the word mamaos means that many things are read, various circumstances and events are in the word mamaos. Moreover, mamaos is divided into several wandas (form)". The wandas entail wanda papantunan, wanda jejemplangan, wanda dedegungan, wanda rarancagan, wanda kakawen, and wanda panambih or sarungsum. Wandas describe some circumstances or events, some describe the state of the country, the beauty of nature, the power of God, and so on (ibid).

There are two forms of values ini Tembang Sunda Cianjuran: cultural values and character values. In this article, we examine the character values in the lyrics of Tembang Sunda Cianjuran. In this regard, the Ministry of National Education Language Center in Zubaedi (2012) reveals that character is "innate, heart, soul, personality, character, behavior". It means that characters can shape an individual.

Intended characters are positive (good) characters. A good character is a life of good behavior and virtue, behaving well towards others (God Almighty, human, and the universe) and towards oneself (Aristotle). This opinion is in line with Lickona (2013) stating that character is the owner of good things. Characteristics are good goals above human quality, whether they are human or not (Ibid). Goodness is affirmed by society and religion throughout the world. Being good has certain ethical criteria, such as: a) determining what is human, 
whole human, virtue and heart, being not selfish, fairness, and honesty, b) increasing happiness and individuals, c) serving the public interest, enabling us to live and work in the community, d) Reaction of nationality reversibility (would you like this?) and universality (do you want everyone in this way to search the same?).

Expected cultural and character education values are religiosity, honesty, tolerance, discipline, hardwork, creativity, independence, democracy, curiosity, national spirit, patriotism, appreciation of achievement, friendship/communication, peace-loving, reading habit, environmental care, social care, and responsibility (Curriculum of the Ministry of National Education). Among others, eight characters of conservation are proposed by Unnes, as Khusniati (2014) explains, entailing religiosity, honesty, intelligence, care, tolerance, democracy, hardiness and politeness. These values will certainly cultivate other characters suach as fairness, responsibility, and patriotism.

Regarding the character, previous research about Tembang Sunda Cianjuran focused more on the study of the inheritance system of its values to the community, describing Tembang Sunda Cianjuran. The study explained that Tembang Sunda Cianjuran, as a traditional art born in the royal environment, has its own aesthetic matter, behavior from sitting position, communication in nonverbal form when performing, accompanied by music signs and music interaction between player and audience with appreciation depth of both (Julia \& Supriyadi, 2017). This illustrates, there is the cultivation of character values from behavior when developing Cianjuran Sundanese Songs, aside from lyrics that are full of cultural values. Nevertheless, the study leaves the gap for emphasizing the analysis of character manifested in the lyrics of Cianjuran Sundanese songs. With regard to this, the study is aimed at investigating character values contained in five Tembang Sunda Cianjuran.

\section{METHOD}

The method in this research was descriptive analytic method (determining, processing, and popularizing the actual and factual phenomena scientifically). Five Tembang Sunda Cianjuran were used as the sample, comprising Laut Kidul (The South Sea), Mairan ti Dapur Yayasan Wargi Cianjur (Donations from the 
kichen of the Cianjur Foundation), Itu Gunung Naon, Raden? (What is that mountain, Raden?), Pamoyanan, dan Kidung Wiwitan. These were selected as the sample of the research in accordance with the purposive sampling, where the samples are involved in purpose so as to help in addressing the aim of this research. Concerning this, the selection of the songs were based upon three considerations vis-à-vis their lyrics which are easily understandable, full of character values and highly related to the locality of Cianjur.

The techniques of collecting the data included documentary techniques and content analysis. Following this, the data were analyzed, described and concluded. Before the data were described and concluded, coding was carried out to allow for simplification of the songs titles as well as for the sake of clear interpretations of each finding. For instance, TSC-01 was used to refer to Laut kidul, TSC-02 represents Mairan ti Dapur Yayasan Wargi Cianjur, TSC-03 indicates, Itu Gunung Naon, Raden?, TSC-04 denotes Pamoyanan, and TSC-05 constitutes Kadung Wiwitan. Moreover, coding process was the starting point to categorize the data on a table based upon character prevailing in the songs, which were later be presented and interpreted.

\section{RESULT AND DISCUSSION}

The result of each song in relation to character realization in its lyricis is presented in advance of the discussion to take up a stance of the findings in relation to other theories or previous studies. The result of analysis of the character values in five Tembang Sunda Cianjuran is presented in Table 1.

Table 1 Character Values in Tembang Sunda Cianjuran

\begin{tabular}{llllll}
\hline Character Value & TSC- & TSC- & TSC- & TSC- & TSC- \\
& $\mathbf{0 1}$ & $\mathbf{0 2}$ & $\mathbf{0 3}$ & $\mathbf{0 4}$ & $\mathbf{0 5}$ \\
\hline Religiosity & - & $\sqrt{ }$ & - & - & $\sqrt{ }$ \\
Honesty & - & $\sqrt{ }$ & - & - & - \\
Discipline & - & - & - & $\sqrt{ }$ & \\
Hardwork & - & $\sqrt{ }$ & - & $\sqrt{ }$ & \\
Creativity & - & $\sqrt{ }$ & - & - & $\sqrt{ }$ \\
Curiousity & - & $\sqrt{ }$ & $\sqrt{ }$ & - & $\sqrt{ }$ \\
National spirit & - & $\sqrt{ }$ & - & - & - \\
Patriotism & $\sqrt{ }$ & $\sqrt{ }$ & - & $\sqrt{ }$ & $\sqrt{ }$ \\
Appreciation of achievement & - & - & - & $\sqrt{ }$ & $\sqrt{ }$ \\
Communication & - & $\sqrt{ }$ & - & - & - \\
Reading habit & - & $\sqrt{ }$ & - & - & - \\
Environmental care & $\sqrt{ }$ & - & $\sqrt{ }$ & - & - \\
Responsibility & - & - & - & $\sqrt{ }$ & $\sqrt{ }$ \\
\hline
\end{tabular}


Based on data from the analysis, it can be seen that there are thirteen character values in the lyrics of Sundanese Cianjuran songs. Of all the songs, TSC-02 has the highest number of realized character values with 9 character values manifested. In the meantime, TSC-01 and TSC-03 have the least realized characters with only 2 character values.

In addition, out of the five songs (tembang), there are two songs that contain religious values, namely TSC-02 and TSC-05; one song contains honest value (honesty), TSC-02; one song contains discipline values, TSC-04; two songs contain hard work values (TSC-02 and TSC-04); creative values contained in two songs, TSC-02 and TSC-05; three songs contain the value of curiosity (TSC-02, TSC-03, and TSC-05); one song contains the value of national spirit (TSC 02); four songs contain the value of love for the homeland (TSC-01, TSC-02, TSC-04, and TSC-05); the value of appreciating achievement is contained in two songs (TSC-04 and TSC-05); communicative value is contained in one song, namely TSC-02; one song contains the value of reading likes (TSC-02); two songs contain environmental values (TSC-01 and TSC-03), and two songs contain values of responsibility (TSC-04 and TSC-05). The most dominant character value found in the five songs is the patriotism value (4 songs). Each character representation in the songs is going to be depicted in detail as follows.

\section{Character Values in Tembang Sunda Cianjuran \\ Religiosity}

Religiosity values can be seen from attitudes and behaviors that show adherence in carrying out their religious teachings, tolerant of the worship of other religions, and live in harmony with adherents of other religions. It is clearly described as follows.

a) Neda agung pangaksama Hakeki ka Mahasuci

(Request permission from the Almighty) TSC-02/1-2

b) Neda ampun ka Yang Agung

Seja amit ka Yang Widi (asking forgiveness from the Almighty, asking for pleasure) TSC-05/1-2

Disuhunkeun barokahna

Ti sadaya para wali

(ask for blessings from the guardians) TSC-05/3-4 
Religiosity is one of character values. Having religious and faithful character will build an individual's good attitudes and behavior and denotes great faith in the Creator, in God. This will create an individual obedient in worship and behaving in compliance with the religion and with what is forbidden (Herawan \& Sudarsana, 2017).

\section{Honesty}

Honesty values can be reflected in behavior based on the effort to make himself a person who can always be trusted in words, actions, and work. Honest values are found in TSC-02 in the fifth and sixth lyrics.

Sanes ati kumaki

Reh agul ku payung butut

(not haughty and arrogant) TSC-02/5-6

The excerpt exemplifies honestly saying the true intention before saying or explaining something to others. This value is necessary to be cultivated for the young generation. For instance, honesty, as argued by Herawan \& Sudarsana (2017), constitutes an important element to be cultivated into every individual. Honesty and sport will generate the harmonized relationship between individuals and their God.

\section{Discipline}

Dicsipline value is the value that is realized through well-managed behavior and complies with various provisions and regulations. Discipline values are found in the fifth to tenth TSC-04 lyrics (one unit of meaning).

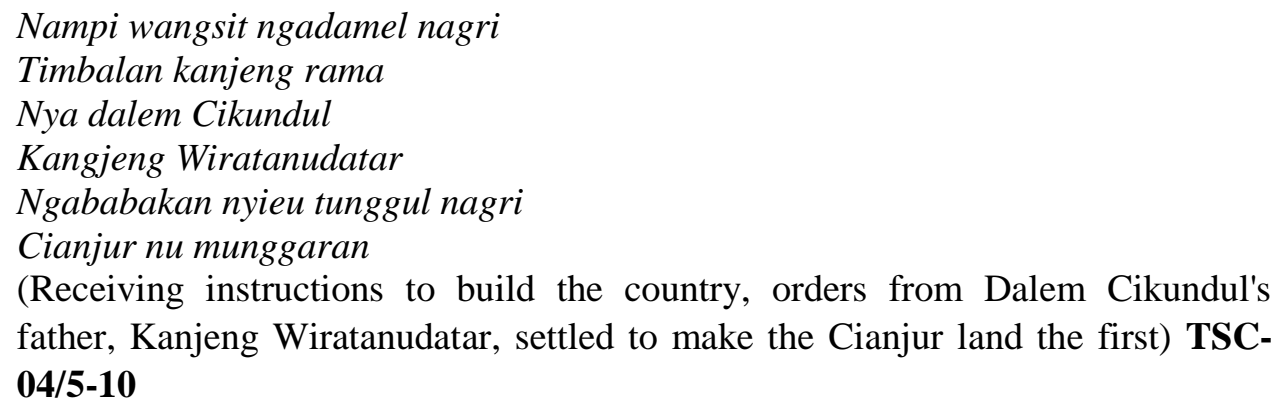

The character contained in the fourth song is required to be cultivated since childhood so it can be guidelines for thinking, saying, and acting in all aspects of life. Lickona (in Apriani \& Wangid, 2015) affirms that a moral education approach to discipline uses discipline as a tool for teaching values of respect and responsibility. this is supported by Nucci and Narvaes (Ibid.) that 'In 
developmental discipline children are viewed as intrinsically motivated to learn achieve competence and to establish mutually caring relationship in a supportive and caring environment'. This implies that submerging discipline to children is supposed to be effective since they are motivated in nature.

\section{Hardwork}

The value of hardwork is manifested in behavior or an effort to be careful in overcoming various barriers of learning and tasks and in completing the task as well as possible. The value of hard work is found in the following song.

Ciri bukti anu nyata

Dugi ka alam kiwari

Gumelar taya pegatna

(being real evidence until now, continuous rolling) TSC-02/19-21

Based on the lyrics, the word "to be a real evidence until now, continuous rolling" (TSC-02/19-21) is the value of hard work, maintaining culture to continue to be preserved.

\section{Creativity}

Creative value is a value that is reflected in the way of thinking and doing something to produce new ways of the existing. Here are the Cianjuran Sundanese songs that contains creative values.

a) Pantun, Jemplang, reujeung Degung

Katut rancaganana

Salendro pon kitu deui

Naha saha nu nyiptakeunana

(Pantun, Jemplang, and Degung, with the tempo of the song, including salendro. Who created it?) TSC-02/34-37

b) Wirehing bade ngaguar

Ngaguar nu jadi kawit

Dina widang tetembangan

Malar teu poekeun teuing

(because it will reveal the origins of the song field, so as not to be forgotten / remain known) TSC-05/9-12

\section{Curiousity}

Attitudes and actions of individuals that always strive to find out more deeply and broadly from what they learn, see, and hear are manifestations of the value of curiosity. Cianjuran Sundanese Songs which contain the value of curiosity are as follows. 
a) Mapay raratan asalna

Ieu mah ibarat misil

Ibaratna anak anu mapay bapa

(looking for origins like a child looking for his father) TSC-02/7-9

b) ari gunung Ciremay teh

tetengger nagara mana?

(Mount Ciremay, which country characteristic?) TSC-03/2-3

c) Wirehing bade ngaguar

Ngaguar nu jadi kawit

Dina widang tetembangan

Malar teu poekeun teuing

(Because it will reveal the origin of the song field, so as not to be forgotten/to remain known) TSC-05/9-12

Curiosity characters are essential to be cultivated in the young generation of the $21^{\text {st }}$ century particularly. This is asserted by Ameliah et al. (in Fauzi, Zainuddin, \& Atok, 2017), that curiosity constitutes the underpinning basis for learners in learning processes. Having the high level of curiosity, learners can learn hard to fulfill their needs of to-be-known knowledge. Such curiosity leads them to start learning and and discovering something.

\section{National spirit}

The value of national spirit is manifested in ways of thinking, acting, and insights that place the interests of the nation and the country above their selves and group interests. The value of national spirit is found in the lyrics of the following Tembang Sunda Cianjuran.

\section{Tembang Sunda Cianjuran \\ Geus jadi sabiwir hiji \\ Jadi catur balarea \\ Tapi poma ulah lali \\ Sajarahna mimiti}

(Tembang Sunda Cianjuran has been the talk of many people, but don't forget its original history) TSC-02/28-32

\section{Patriotism}

Patriotism is the most frequently realized character in the five songs. It is reflected in ways of thinking, behaving and acting that show loyalty, care, and high appreciation for the language, the nation's physical, social, cultural, economic, and political environments. The lyrics of Cianjuran Sundanese songs which contain the value of patriotism are the following.

a) Gunung Gede jiga nu ngajakan balik Abdi kalunta lunta 
(Gunung Gede is seemingly taking me home, my self is left) TSC-01/9-10

The values contained in TSC-01 (the first song) is patriotism and care for the environment. Accoring to Herawan \& Sudarsana (2017), the character of patriotism is the realization of individuals' loyalty to the country in which they live. Therefore, if people of a country possess this character, the will and courage to develop the country will be pursued, which is in turn beneficial for the community.

\section{Appreciation of achievement}

Attitudes and actions that encourage human to produce something useful for the community, and recognize and respect the success of others are manifestations of the values of achievement appreciation. The values in the lyrics of Tembang Sunda Cianjuran are presented in the following excerpts

a) Sajarah pon kitu deui

Ngandung warsi mimiti

Saha nu ngadeg papayung

Catetan mere jawaban

Sajarah geus mere bukti

(Likewise history, which explains the origin, who leads, answers are all recorded, becomes historical evidence) TSC-02/13-17

b) Pamoyanan jadi cari bukti

Patilasan bupati baheula

Nelah Kanjeng Tarikolot

Nu ngawangun Cianjur

(Pamoyanan is historical evidence, the legacy of the former regent, known as Kanjeng Tarikolot who built Cianjur) TSC-04/1-4

c) Disuhunkeun barokahna

Ti sadaya para wali

Para ahli jeung pujangga

Pujangga anu bihari

(Request blessings from the trustees, experts and poets first) TSC-05/3-6

The excerpts show the value of appreciating achievement in any way possible. It is exemplified that we must appreciate song creators accordingly. This value can be implemented in today's interaction that any works created, written or spoken, should be praised and used with courtesy. 


\section{Communication}

Actions that show pleasure in talking, associating, and collaborating with others are attitudes that reflect communication values. The lyrics on TSC-02 have this value, as shown below along with the lyrics and their meanings.

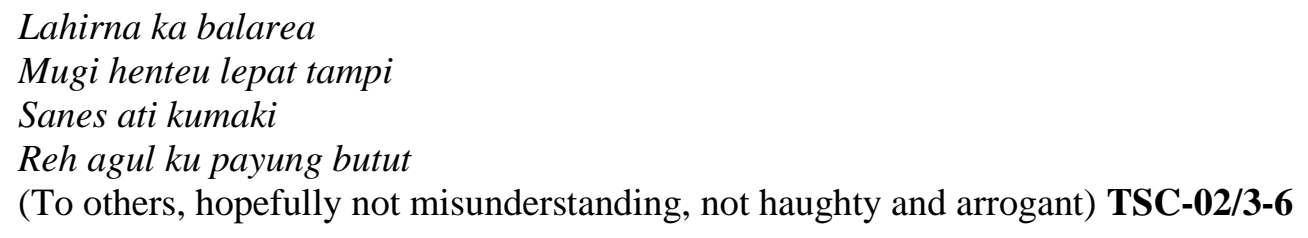

\section{Reading habit}

The value of reading habit is illustrated in the habit of providing time to read various readings that give benefits to an individual. This value is implicitly expressed in the lyrics below.

\section{Seni kabudayaan Sunda}

Ku urang kudu talungtik

(Sundanese cultural art, we need to examine) TSC-02/20,26

The sentence $k u$ urang kudu talungtik or we need to examine is the reflection of reading habit since investigating something needs reading. The primacy of cultivating reading habit can be seen from national literacy act in school level. This must persist because based on the data in Progress of Interational Reading Literacy study (PIRLS) in 2011 indonesian students' ability to comprehend texts is lower than the international average (Akbar, 2017). This to some extent shows that this character is poorly implemented by students. The prevalence of this character on the Cianjuran Sundanese songs should have bolstered their character as it seems to have been held by the community.

\section{Environmental care}

Attitudes and actions that always avert damage to the environment, and develop efforts to repair the damage that has occurred into an environment constitute cares for the environment. The character values that are caring for the environment include a number of lyrics as the following excerpts show.

a) Ari gunung $n u$ Wetan

Baheula Sumedang Larang, Juragan

Sumedang sasaka Domas

Lain gunung tanpa omas

(The east mountain used to be Sumedang Larang, Juragan. Sumedang sasaka Domas, not a mountain without gold) TSC-03/4-7 
b) Ari gunung Pangrango teh

Tetenggerna dayeuh Bogor, Juragan

Kapungkur tilas karaton

Batu tulis cicirenna

(Mount Pangrango is the character of city of Bogor, Juragan, formerly it was a palace, the slate became its characteristic) TSC-03/28-31

It is shown that the word "mountain" is represented as the environment which is typical of Cianjuran Sundanese songs as it is frequently scripted on the lyrics. Concerning the environmental care, the values that an individual must hold is preserving the environment, in this sense the mountains. In similar vein, Dalyono \& Lestariningsih (2017) affirm that the value of environmental care is attitudes and actions which are carried out to avoid bad effect on and to keep on mending what is damaged in the surrounding environment.

\section{Responsibility}

The attitude and behavior of a person that is carried out during duties and obligations towards themselves, society, the environment (natural, social and cultural), the state and God Almighty, is a depiction of the value of responsibility. The values of responsibility analyzed in the five songs are found as follows.

a) Nampi wangsit ngadamel nagri

Timbalan kanjeng rama

Nya Dalem Cikundul

Kangjeng Wiratanudatar

Ngababakan nyieun tunggul nagri

Cianjur nu munggaran

(receiving instructions to build the country, ordered of father Dalem Cikundul, Kanjeng Wiratanudatar, who was settle and build the first Cianjur) TSC-04/5-10

b) Ieu para putra putu

Nu mupusti kana seni

Nu micinta tetembangan

Ulah kasilih ku junti

Henteu kagembang ku jaman

Karawat ku nu pandeuri

(The successors who take good care of art, who love song, not to be displaced by other cultures, eroded by the flow of time, must be looked after and up to the next generation) TSC-05/19-24

By looking out the excerpts, the responsibility value must be emphasized as early as possible since being responsible means brave, ready, and resolute in accepting decisions and actions carried out intentionally or unintentionally. This means that an individual is responsible if the individual thoughtfully decides something and readily deals with all the possible outcomes. The individual will 
not escape what he did and be responsible for it as well as blame no one (Suparno, dalam Apriani \& Wangid, 2015). A responsible individual will make a better decision.

\section{CONCLUSION}

What can be concluded is that thirteen character values are realized in the five Cianjuran Sundanese Songs; Religiosity, Honesty, Tolerance, Discipline, Hardwork, Creativity, Independence, Democracy, Curiousity, National spirit, Patriotism, Appreciation of achievement, Communication, Peace loving, Reading habit, Environmental care, Social care, and Responsibility. This finding denotes an array of virtues which could be generated from the local wisdom and culture as they are enthrenched in the community. These character values can be implemented in the learning of character building. Besides building character values, these can also introduce Cianjur culture or Sundanese culture to the young generation. Thus, the Sundanese culture, Cianjuran Sundanese songs in particular, can be lapped up by people over generations. Despite its findings and contributions, this study is limited to Sundanese songs of Cianjur, allowing for further research to analyze Sundanese songs in other regions of Parahyangan or to investigate the implementation in learning Bahasa Indonesia.

\section{ACKNOWLEDGEMENTS}

This article could be fulfilled by the moral and material support from several parties, especially the Directorate of Research and Community Service of the Ministry of Research, Technology, and Higher Education which funds the implementation of research. In addition, motivation and support from the LPPM of Suryakancana University, the Teaching and Education Faculty, the Indonesian Language Education Study Program, and colleagues, so that this article can be completed properly. The authors thank all parties who have supported the publication of this research.

\section{REFERENCES}

Adawiyah, A., \& Munsi, M. F. (2018). Mengeksplorasi Nilai-nilai Budaya Tembang Sunda Cianjuran. Jurnal Bahasa, Sastra, dan Pembelajarannya, 8(1), 132-143. DOI:http://dx.doi.org/10.20527/jbsp.v8i1.4818 
Akbar, A. (2017). Membudayakan Literasi Dengan Program 6M di Sekolah Dasar. Jurnal Pendidikan Sekolah Dasar, 3(1), 42-52. https://doi.org/https://doi.org/10.30870/JPSD.V3I1.1093

Apriani, A. N., \& Wangid, M. N. (2015). Pengaruh SSP tematik-integratif terhadap karakter disiplin dan tanggung jawab siswa kelas III SD. Jurnal Prima Edukasia, 3((1)), 12-25. https://doi.org/https://doi.org/10.21831/JPE.V3I1.4061

Dalyono, B., \& Lestariningsih, E. D. (2017). Implementasi Penguatan Pendidikan Karakter di Sekolah.. Bangun Rekaprima, 3(April), 33-42. https://doi.org/https://doi.org/10.1111/j.1469-8986.1974.tb00542.x

Fauzi, A. R., Zainuddin, \& Atok, R. Al. (2017). Penguatan Karakter Rasa Ingin Tahu dan Peduli Sosial melalui Discovery Learning. Jurnal Teori dan Praktis Pembelajaran IPS, 2(2), 27-36.

Gufron, A. (2010). Integrasi Nilai-Nilai Karakter Bangsa pada Kegiatan Pembelajaran. Jurnal Ilmiah Pendidikan, Cakrawala Pendidikan, XXIX(Mei), 13-14. https://doi.org/https://doi.org/10.1016/J.PRP.2014.03.014

Herawan, K. D. \& Sudarsana, I. K. (2017). Relevansi Nilai Pendidikan Karakter dalam Geguritan Suddhamala untuk Meningkatkan Mutu Pendidikan di Indonesia. Jurnal Penjaminan Mutu, 3(2), 223 - 236.

Hermawan, D. (2014). Fenomena Gender dalam Dongkari. Panggung, 24 No.1(212), 25-38.

Hotimah, H. H. (2018). Semiotic and Etnopedagogy Study of Lyrics Tembang Sunda Cianjuran. Alinea, 1(3), 194-203.

Ihgbal, M. (2017). Internalisasi Nilai-nilai Budaya dalam Seni Mamaos di Tengah Era Globalisasi. Repository.upi.edu/perpustakaan.upi.edu

Ischak, C. A. (2006). Mengenal Tembang Sunda Cianjuran. Cianjur: Liebe Book Pres.

Julia \& Supriyadi, T. (2017). The inheritance of values in Sundanese song of Cianjuran in West Java. Harmonia: Journal of Arts Research and Education, 17(2), 120. https://doi.org/https://doi.org/10.15294/harmonia.v17i2.8645

Khusniati, M. (2014). Model Pembelajaran Sains Berbasis Kearifan Lokal Dalam Menumbuhkan Karakter Konservasi. Indonesian Journal of Conservation, $3(1), 67-74$.

Lickona, T. (2013). Character Matters. (U. Wahyudin \& D. Budimansyah, Eds.). Jakarta: Bumi Aksara. 


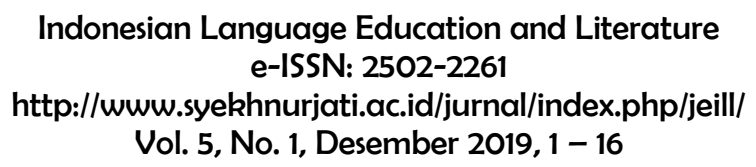

Maryam, S. (2012). Menjawab Tantangan Global dengan Mengembangkan Potensi Lokal: Studi Kasus Pada Budaya dan Literasi Masyarakat Cianjur. Atikan: Jurnal Kajian Pendidikan, 2(2), 273-286.

Maulana, M. H. I. (2018). 7 Pilar Budaya Kabupaten Cianjur. Retrieved November 6, 2018, from https://budaya-indonesia.org/7-Pilar-BudayaKabupaten-Cianjur

Natamihardja, D. R. (2009). Ngaguar Mamaos Cianjuran. Cianjur: Lembaga Kebudayaan Cianjur.

Supriyono, S., Wardani, N. E., \& Saddhono, K. (2018). Nilai Karakter Tanggung Jawab Dalam Sajak-Sajak Subagio Sastrowardoyo. RETORIKA: Jurnal Bahasa, Sastra, dan Pengajarannya, 11(2), 183. https://doi.org/. https://doi.org/10.26858/retorika.v11i2.6370

Wiradiredja, M. Y. (2012). Peranan R. A. A. Wiranatakusumah V dalam Penyebaran Tembang Sunda Cianjuran. Jurnal Seni \& Budaya Panggung, 22(3), 283-292.

Zubaedi. (2012). Desain Pendidikan Karakter. Jakarta: Kencana. 